\title{
The Roots of Existentialism in the Augustinian Person
}

John Paulo Juliano

\begin{abstract}
This paper is an exposition of the existential concepts of subjectivity, despair, and passion within the theoretical framework of the philosophy of Augustine of Hippo or more commonly known as St. Augustine. I will be focusing on Augustine's central works which are the Confessions, On the Trinity and On the Free Choice of Will. This paper will be divided into two parts. The first part will discuss the basic ideas of the existential approach, centering on the concepts of subjectivity, despair and passion as conceptualized by the early existentialists such as Søren Kierkegaard and Friedrich Nietzsche. The second part of this paper will expose the different concepts of Augustine that express the fundamental notions of subjectivity, despair, and passion. For this part I will focus on Augustine's concepts of human dignity, original sin, and the inward journey of the self, which all constitute Augustine's notion of the human person as a whole. The entire article will also provide deep connections among the mentioned figures of philosophy that center on man and his identity as a subject.
\end{abstract}

Keywords: human dignity, identity, inward journey, existentialism

\section{The Development of Existentialism}

$\mathrm{P}$ hilosophy in its entire course has dealt with the very aspect of humanity. Its focus, shifting from a curiosity for the cosmos to the creatures living within it, has laid before itself an interest for man himself. It is in the subject of man that will complete his knowledge. With this in mind, the human individual is constantly searching for his own self-worth: the viability and authenticity of his existence. It is true that man naturally desires the truth, even the truth for himself. Yet this truth is not only the truth of the world around him, but his own truth.

(c) 2016 John Paulo Juliano

http://www.kritike.org/journal/issue_19/juliano_december2016.pdf

ISSN 1908-7330 
Human individuals are capable of establishing relationships in two ways: (1) the ability to relate to external reality and (2) the ability to relate to oneself. A number of epistemological and metaphysical theories have taught us that to relate to the external reality is to know reality itself. ${ }^{1}$ As James Collins puts it: "Metaphysics is grounded, however, not in a pretended comprehensive insight into reality as a whole but in the human mind's ability to recognize that the existent thing is indeed an insistence of being." 2 The human mind is capable of relating to his outside existence, and the relation built by this awareness provides an experience of reality itself not necessarily in its fullness but in a single concrete horizon. It becomes the source of knowledge for the human individual who relates himself with his world. Hence this constitutes the human individual's first mode of relationship. This form of relationship shall be referred to as the outward journey.

Yet there is a mode of relationship deeper than what the outward journey provides. Human individuals are not simply objects in a myriad of existents that constitute reality. A human individual is self-aware, attuned to his internal senses, and is able to grasp the truth that he exists. He is aware of the world and its objectivity, yet he is also capable of knowing himself as a subject. Maurice Merleau-Ponty reflects this truth when he says that "the subject that I am, when taken concretely, is inseparable from this body and this world." 3 The human individual is not simply an object. He is, therefore, a self-aware subject. This is the inward journey.

The human individual as a subject is the primary concern of existentialism. Focusing on topics such as the subject and his experience, existentialism centers on the uniqueness of the subject, as something that "exists in a way that is different from other things-such as trees, cultural artifacts and animals." 4 The subject's manner of existing is different as well as his relating to existence itself. Existentialism is grounded upon the existing, single individual, who is capable of both knowing and experiencing external

${ }^{1}$ However, we must make the fundamental distinction that to know reality does not necessarily mean reality in its entirety. Epistemological theories mainly present our acquisition of knowledge, and not the constitution of external reality itself. This problem, therefore, is more grounded upon metaphysics.

${ }_{2}^{2}$ James Collins, Crossroads in Philosophy (Chicago: Henry Regnery Company, 1962), 42.

${ }^{3}$ Maurice Merleau-Ponty, Phenomenology of Perception, trans. by Colin Smith (New York: Routledge, 2003), 475. Merleau-Ponty recognizes the fundamental truth of the subject as within a "world." This world is not to be confused with external reality itself in its entirety. World in this context refers to the immediate, conscious environment of the subject, of which is the agent of experience for the human individual.

${ }^{4}$ Kevin Aho, Preface to Existentialism: An Introduction (Cambridge: Polity Press, 2014), xi.

(c) 2016 John Paulo Juliano

http://www.kritike.org/journal/issue 19/juliano december2016.pdf

ISSN 1908-7330

(cc) BY-NC-ND 


\section{THE ROOTS OF EXISTENTIALISM}

reality. ${ }^{5}$ It is from this vantage point that the subject as relating to oneself is given primary concern.

Existentialism traces back its roots to the thinkers of ancient and medieval thought, the most famous of which is Socrates who is known for his saying "know thyself" (gnöthi seauton). It is important to note that during the rise of Greek philosophy the main focus was the identification of the arche of the universe, or the first sustaining principle of matter. Socrates shifted his focus from the cosmological to the anthropological, speaking of the depth of the individual himself and not merely the immediacy of the cosmos. This trend faded for some time and found itself in the beginnings of medieval thought with the philosophy of Augustine of Hippo whose relevance to existentialism, which is the primary objective of this essay, will be discussed in detail after a brief account of the development of existentialism starting from French mathematician and philosopher René Descartes to the Absolute Idealism of Georg Wilhelm Friedrich Hegel.

The development of existential thought continued with the emergence of Cartesian philosophy. He begins with the premise of philosophy as having been "studied for many centuries by the most outstanding minds without having produced anything which is not in dispute and consequently doubtful and uncertain." 6 Descartes' time was marked by the decline of Scholastic thought and the open opposition to the established teachings of the intellectual authorities (i.e., the clergymen). The fall of medieval supremacy has left everyone in question, and Descartes was acutely aware of this predicament. Thinking is doubtful. The age itself demanded an attitude of doubt. Descartes supported this call for doubt, and radically claimed that to achieve a 'new science,' we should apply the method of universal doubt.

From this fundamental theory, Descartes posits his most important contribution to philosophy which is the presence of the Cartesian ego. In his work, the Meditations on First Philosophy, he states that in applying the method of doubt "I too undoubtedly exist," and remarks that "after considering everything very thoroughly, I must finally conclude that this proposition, I am, I exist, is necessarily true whenever it is put forward by me or conceived in my mind." 7 It is from this vantage point that the $I$ has been created by

5 The very famous "subject-object" schema was discussed profusely by several existentialists such as Søren Kierkegaard, Martin Heidegger and Maurice Merleau-Ponty. The main presupposition of existentialism is that "there is no separation between 'inner' and 'outer,' between self and the world." See Aho, Existentialism: An Introduction, 36. Hence, the "subjectobject" schema is an essential unity.

${ }^{6}$ René Descartes, Discourse on Method, trans. by Laurence Lafleur (New York: The Liberal Arts Press, 1960), 8.

${ }^{7}$ René Descartes, Meditations on First Philosophy, ed. and trans. by John Cottingham (Cambridge: Cambridge University Press, 1996), 17. The famous dictum cogito ergo sum embodies

(C) 2016 John Paulo Juliano

http://www.kritike.org/journal/issue 19/juliano december2016.pdf

ISSN 1908-7330

(c) ) BY-NC-ND 
Descartes. It is an I that takes as its reference point his capacity for thought. From Descartes' thinking, two philosophical traditions have been formed: the materialist approach of the empirical tradition, and the idealist attitude of the rationalist tradition.

The development of existentialism through Descartes is focused on the rationalist tradition, tracing its lineage from, aside from Descartes, Baruch Spinoza and Gottfried Leibniz. The influence of these philosophers has created an attitude known as 'dogmatism.' This attitude is primarily linked with the dominance of the rationalist approach, that treats knowledge as something purely of intellectual supremacy. This was the kind of dogmatism that Immanuel Kant possessed in his early years before he became the known thinker he is today. This shift from dogmatism to the transcendental idealism we know of Kant today marks a turning point in the progression of existentialism. The Kantian system, as followed and opposed by its successors, led to the development of yet another important philosophical system: the Hegelian System.

Hegel views the subject-object relationship as the perennial problem in western philosophy; and he theorizes that the history of philosophy is really the history of sometimes discordant, sometimes concerted, efforts to arrive at a solution of this problem. Thus in Hegel's view there is in the strict sense only one philosophical system, historically evolving as it progresses towards this goal. ${ }^{8}$

It is with this system that the entire existential approach began. Tracing its development from the Cartesian cogito, to the development of rationalism, and later on, to the systems of Kant and Hegel, existentialism as a philosophical approach began to make itself known. Existentialism begins with a fundamental premise:

... existentialist philosophers typically deny that the ageold philosophical ambition of articulating a rational

the personification of Descartes universal doubt. This is also how Cartesian philosophy has characterized the subject, as made evident by his capacity of thinking and acknowledging the usefulness of such a method of universal doubt.

${ }^{8}$ Howard Kainz, G.W.F. Hegel: The Philosophical System (New York: Twayne Publishers, 1996), 15. Italics added.

(c) 2016 John Paulo Juliano

http://www.kritike.org/journal/issue 19/juliano december2016.pdf

ISSN 1908-7330 
systematic account of the world and the human beings inhabiting it is anything but a misguided project. ${ }^{9}$

This passage clearly reflects the prominent trait of existential thought as repellant to the idea of a philosophical system. Such prevailing systems during early existentialist thought were seen as something 'dominating' and leaves nothing for the spontaneity of the individual. One such example is the relation of the Hegelian system to the existing individual. Danish philosopher Søren Kierkegaard, regarded as the father of modern existentialism, developed a philosophy which is the very outcry against a domineering force such as the Hegelian System. Kierkegaard's basic premise is that the Hegelian dialectic of history, that focuses on nothing more than an unfolding of historical events towards Spirit (Geist), renders superfluous the identity of the individual within history itself. ${ }^{10}$ In this essay we will be focusing only three important existential concepts: subjectivity, despair, and passion. These concepts will be discussed within the framework of the philosophy of Kierkegaard which will then be used to determine the existential elements found within the philosophy of Augustine of Hippo.

Kierkegaard is known for his vast discussion of the notion of subjectivity. His aversion to the totalizing objectivity of Hegelian philosophy has created a philosophy of subjectivity that searches "back and inward into inwardness." 11 This subjectivity is embodied in what Kierkegaard calls the 'self':

The human being is spirit. But what is spirit? Spirit is the self. But what is self? The self is a relation which relates to itself, or that in the relation which is its relating to itself. A human being is a synthesis of the infinite and the finite, of the temporal and the eternal, of freedom and necessity. In short a synthesis. A synthesis is a relation between two terms. ${ }^{12}$

\footnotetext{
${ }^{9}$ Mark Tanzer, On Existentialism (California: Thomson Wadsworth, 2008), 2. Italics added.

${ }^{10}$ It becomes a primary contention that the entire Hegelian System, together with the dialectic it has within it, is the supposed death of the individual himself who is nothing more than a mere spec of the majority of the 'they.' Existentialism's antipathy towards philosophical systems is grounded upon the fact that the individual himself has no capacity whatsoever to build upon his own subjectivity, and leaves him disabled to remove himself from mass conformity to the system.

${ }^{11}$ Søren Kierkegaard, Concluding Unscientific Postscript to Philosophical Fragments, trans. by Howard and Edna Hong (New Jersey: Princeton University Press, 2004), 33.

${ }^{12}$ Søren Kierkegaard, Sickness Unto Death, trans. by Alastair Hannay (London: Penguin Books, 2008), 9. Italics added.

(c) 2016 John Paulo Juliano

http://www.kritike.org/journal/issue 19/juliano december2016.pdf

ISSN 1908-7330

(c) BY-NC-ND
} 
Subjectivity emphasizes a 'return to self' similar to the earlier mentioned inward journey. It is a perspective whose object is oneself. However, it is not only through this self-awareness that Kierkegaard defines subjectivity. It is also through the presence of choice and intersubjective communication. He mentions an ethical task of becoming a self, which consists in an acute awareness of choosing for oneself. The self as explained by Kierkegaard thus argues "that it is its own end and purpose and comes into existence as a result of the choice."13 $\mathrm{He}$ also mentions the need for intersubjective communication or, in Kierkegaardian terms, indirect communication:

Double-reflection is already implicit in the idea of communication itself: that the subjective individual, existing in the isolation of inwardness, wants to communicate himself, consequently that he simultaneously wants to keep his thinking in the inwardness of his subjective existence and yet wants to communicate himself. It is not possible for this contradiction to become manifest in a direct form. ${ }^{14}$

Through communication, the subject builds relationships with other subjects. It is evident that Kierkegaard gives emphasis on the subject, but also mentions the subject's ability to communicate himself, yet remains in the inwardness of his subjectivity. In his communicating, he does not alienate himself from the subjectivity that he possesses.

The second important existential concept is called despair. Kierkegaard puts it simply in three forms: "not being conscious of having a self, not willing to be oneself, but also despair at willing to be oneself. Despair is 'sickness unto death.'" 15 The basic message of despair is the failure to be a subject, meaning that subjectivity as consisting of a self-aware, free, and intersubjective existence, lacks in one or two aspects. Despair is discussed in length by Kierkegaard when he speaks of the spheres of existence: the

${ }^{13}$ Domingos Sousa, "Kierkegaard's Anthropology of the Self: Ethico-Religious and Social Dimensions of Selfhood," in The Heythrop Journal, 53:1 (2012), 38. This enables choice to become a primary requirement for the attainment of selfhood. With the inclusion of choice, freedom also becomes an element that must be present for the full realization of subjectivity.

${ }^{14}$ Kierkegaard, Postscript, 159. Kierkegaard speaks here of the faculty of the self to communicate. This brings to mind several arguments against Kierkegaard's subjectivity, branding it a 'solipsistic' and 'individualistic' philosophy. Communication is necessary because it is an inherent ability of the subject himself. And that his subjectivity also rests on the capacity for communication.

${ }^{15}$ Kierkegaard, Sickness Unto Death, 2.

(c) 2016 John Paulo Juliano

http://www.kritike.org/journal/issue 19/juliano december2016.pdf

ISSN 1908-7330 
aesthetic, ethical, and religious spheres. The shift from one sphere to another lies in the presence of despair. Therefore, despair is necessary for the actualization of the self. This brings us to the last important existential concept to be discussed: passion.

What unites all human beings is passion. So religious passion, faith, hope and love are everything - the great thing is to live one's life in what is essential for all human beings, and in that to have a difference of degree. Being a philosopher is just about as good a difference as being a poet. ${ }^{16}$

Kierkegaard continually focuses upon the need for passion-a passion that is the unifying factor and catalyst. This passion then is the infinite passion of inwardness. ${ }^{17}$ By this passion the individual is empowered to live, and to live authentically and genuinely. Therefore, subjectivity lies not only in self-awareness, choice, and inter-subjectivity, nor on the recognition of despair, but on the inner workings of the spirit. ${ }^{18}$ Hence, one can see that existentialism as a whole centers on the inner journey of the individual, and how the individual relates not only to external reality but also to his inner workings.

\section{Augustinian Thought as Existentialist Precursor}

The previous part of this essay discussed the development of existentialism from René Descartes up to Søren Kierkegaard, whose philosophy we are using as the context of our discussion on existentialism. It was also mentioned that existentialism does not precisely begin with Cartesian philosophy, but can also be found in the ancient (e.g. Socratic philosophy) and the medieval times. The most pertinent form of medieval thought that expresses the earliest traces of existentialism is found in the philosophy of Augustine of Hippo (354-430CE). The following discussion will be an exposition of the three concepts of existentialism: subjectivity, despair, and passion within the philosophy of Augustine of Hippo, giving greater attention to the notion of subjectivity, which is the very heart of existentialism. This exposition will be based on Augustine's own writings,

\footnotetext{
16 Søren Kierkegaard, Papers and Journals: A Selection, trans. by Alastair Hannay (London: Penguin Books, 1996), 177.

${ }^{17}$ Ben Alex, Soren Kierkegaard: An Authentic Life (Copenhagen: Scandinavia Publishing House, 1997), 82.

${ }_{18}$ This refers to the passions and drives of the individual. 
and will present Augustinian philosophy as a precursor to the existentialist thought known in the present time.

Still he desires to praise thee, this man who is only a small part of thy creation. Thou hast prompted him, that he should delight to praise thee, for thou hast made us for thyself and restless is our heart until it comes to rest in thee. ${ }^{19}$

The opening chapter of Book I of the Confessions gives us a preview of the entirety of Augustine's philosophy. It was a struggle, and this truth is known by Augustine. The entire duration of the Confessions give an account of how Augustine dealt with this struggle-a struggle to which he has devoted his whole life to. He was in constant search for the truth, and this truth has led him to nothing more than an awareness of his own incapacity and wretchedness:

The house of my soul is too narrow for thee to come in to me; let it be enlarged by thee. It is in ruins; do thou restore it. There is much about it which must offend thy eyes; I confess and know it. ${ }^{20}$

Augustine's entire philosophical work is characterized not only as a struggle but also an identification of oneself. ${ }^{21}$ It is primarily seen as a Christian philosophy, meaning that its assertions are more or less aimed at a 'philosophizing' of the truths of Christianity. His primary philosophical predilection is the Neo-Platonist tradition:

By having thus read the books of the Platonists, and having been taught by them to search for the incorporeal Truth, I saw how thy invisible things are understood through the things that are made. And, even when I was thrown back, I still sensed what it was that the dullness of my soul would not allow me to contemplate. ${ }^{22}$

${ }^{19}$ Augustine of Hippo, The Confessions of St. Augustine, trans. by Albert Cook Outler (New York: Dover Publications, 2014), 1.

${ }^{20}$ Augustine, Confessions, 4. This passage in itself echoes an understanding of the modern concept of subjectivity. Italics added.

21 Some key features of Augustinian philosophy also touch other important philosophical topics such as the problem of evil, time and even the cosmological existence of the world in relation to the supremacy of God. These features, however, will not be discussed in order to focus on some of Augustine's concepts that are pertinent to the aim of this essay.

${ }^{22}$ Ibid., 124.

(c) 2016 John Paulo Juliano

http://www.kritike.org/journal/issue 19/juliano december2016.pdf

ISSN 1908-7330 
Thus, Augustinian philosophy can be characterized by an inner struggle not only with the truths of the world but also with the truths of God, and how these truths can satisfy an 'innate desire' for it. Such an introduction, however, would not suffice in speaking for the breadth of Augustine's philosophical thought. Having laid down the fundamental characteristics of Augustinian philosophy, we now turn to the three existential concepts and how they can be found within Augustinian philosophy.

\section{The Augustinian Notion of Subjectivity}

The concept of subject is one of the fundamental concepts of existentialism as stated in the previous discussion. The individual, who possesses his subjectivity, is unique, unified, and authentic. To be a subject in the existentialist point of view is to uphold an identity that distinguishes yourself from other beings. In Augustine's philosophy, the concept of subjectivity can be seen in his concepts of (1) human dignity and (2) free will. These are the two themes that are of great import in presenting the earliest traces of existentialism within Augustinian thought, specifically in his notion of subjectivity.

\section{On Human Dignity}

Augustine in his writings mentions an 'inner self' that most scholars believe is the term designated for person or subject. This inner self is known by man's capacity for thought and the possession of an intellect. Augustine classifies this as 'mind' or 'reason.' In his work On the Trinity, he mentions the role of the mind or reason in knowing the essence of the person:

Then what shall we say? That the mind knows itself in part, and in part does not know itself? But it is absurd to claim that it does not know as a whole what it knows. I do not say that it knows wholly, but that what it knows, it knows as a whole. When it, therefore, knows something of itself which it cannot know except as a whole, it knows itself as a whole. But it knows itself as knowing something, nor can it, except as a whole, know anything. Therefore, it knows itself as a whole. ${ }^{23}$

${ }^{23}$ Augustine of Hippo, On the Trinity, trans. by Stephen McKenna (Cambridge: Cambridge University Press, 2002), 48.

(c) 2016 John Paulo Juliano

http://www.kritike.org/journal/issue 19/juliano december2016.pdf

ISSN 1908-7330

(cc) BY-NC-ND 
This passage acknowledges the presence of the perceiver himself who, capable of observing external reality, knows that it is not only what is outside that exists but what is inside. This recognition of 'inwardness' is a classic expression of the person. ${ }^{24}$ Augustine continues:

Finally, when the mind seeks to know itself, it already knows that it is a mind, otherwise, it would not know whether it seeks itself and perhaps would seek one thing for another. For it might possibly be that it is not a mind, and so while it seeks to know a mind, it does not seek itself. Wherefore, since the mind, in seeking what the mind is, knows that it seeks itself, it certainly knows that itself is a mind. ${ }^{25}$

The person, who seeks his own identity, knows from the very beginning that he is a person. His aspiration for self-awareness is perfected at the outset of his search. Thus, we can see that personhood in Augustine is closely linked with the role of reason. But it is also noteworthy to point out how reason is not the sole essence of being a person, but in the resemblance or image of the Divine when Augustine says that "the most exalted Trinity itself, the most omnipotent God the Creator, in whose image man has been made." ${ }^{26}$ For Augustine, our knowing is precisely an image of the Divine.

And so there is a certain image of the Trinity: the mind itself, its knowledge, which is its offspring, and love as a third; these three are one and one substance. The offspring is not less, while the mind knows itself as much as it is; nor is the love less, while the mind loves itself as much as it knows and as much as it is. ${ }^{27}$

Thus, the person in Augustine is one who possesses an awareness of himself through his reason. Yet this reason is not his alone but is sourced from the Divine. It is through his reason that he is an image. The very essence of being a human person for Augustine is the possession of rationality. ${ }^{28}$ Human

${ }^{24}$ Yet we must not confuse the term 'inwardness' as a kind of self-enclosure. The person in Augustine is not contained in an isolated realm.

${ }^{25} \mathrm{Ibid}$. Italics added.

${ }^{26}$ Augustine, On the Trinity, 38.

${ }^{27}$ Ibid., 40.

28 "So, when we know God, although we become better than we were before we knew Him, and especially when this knowledge being liked and loved worthily, is a word, and thereby produces some similarity to God. Yet that knowledge is less than He is, because it is in a lower nature; for the mind is creature, but God is Creator." See Augustine, On the Trinity, 37. Mind, for

(c) 2016 John Paulo Juliano

http://www.kritike.org/journal/issue 19/juliano december2016.pdf

ISSN 1908-7330

(cc) BY-NC-ND 
dignity, then, is composed of an interplay between the 'inner self' and the nature of man as 'imago Dei.' This is the source of human dignity for Augustine.

\section{On Free Will}

Central to the discussion of subjectivity in existentialism is the concept of free will or freedom. Jean-Paul Sartre, a known French existentialist philosopher, gave us a glimpse of this necessity in his work Being and Nothingness. Sartre argues that freedom in itself is a necessary precondition for the subjectivity of man. ${ }^{29}$

For Augustine, subjectivity does not only include the presence of selfawareness manifested by the 'inner self' and the nature of man as imago Dei. Augustine also mentions the importance of free will to know the nature of the person. In his work On the Free Choice of the Will, he mentions that "if human beings lacked free choice of the will, how could there be the good in accordance with which justice itself is praised in condemning sins and honoring right deeds?" 30 The necessity of free will lies on the fact that without it, man cannot properly exercise his subjectivity. Augustine continues:

If a person is something good and could act rightly only because he willed to, then he ought to have free will, without which he could not act rightly. We should not believe that, because a person also sins through it, god gave it to him for this purpose. The fact that a person cannot live rightly without it is therefore a sufficient reason why it should have been given to him. ${ }^{31}$

Augustine, is an essential part of being a person. Man's subjectivity is linked to the possession of mind, and how this mind is a vestige of God's own, albeit having a lower nature than its source. In Book IX of De Trinitate, he also speaks of love as an essential part of being in imago Dei. However, this would go beyond the concern of this essay but is also of great import to Augustine's argument.

29 "When I constitute myself as the comprehension of a possible as my possible, I must recognize its existence at the end of my project and apprehend it as myself, awaiting me down there in the future and separated from me by a nothingness. In this sense, I apprehend myself as the original source of my possibility, and it is this which ordinarily we call the consciousness of freedom." Jean-Paul Sartre, Being and Nothingness, trans. by Hazel Barnes (New York: Pocket Books, 1971), 41. Italics added.

${ }^{30}$ Augustine of Hippo, On the Free Choice of the Will, On Grace and Free Choice, and Other Writings, trans. by Peter King (Cambridge: Cambridge University Press, 2010), 32. This passage seems to give us a moral undertone, saying that free will is necessary because of the emergence of goodness from the actions of man. However, it can also be argued that this potentiality for action, which emanates from the mind of man, can also be seen as a source of subjectivity for the free will.

${ }^{31}$ Ibid., 31.

(c) 2016 John Paulo Juliano

http://www.kritike.org/journal/issue 19/juliano december2016.pdf

ISSN 1908-7330

(cc) BY-NC-ND 
Augustine clearly states the importance of free will in the accomplishment of good actions. He argues that God gave free will to men in order for them to be able to do good things. Man, created in his image, is endowed not only with self-awareness but with freedom through the bestowal of free will. The essential characteristic of the person in Augustine is not only an awareness of himself, but a possession of free will given by God. This freedom is in itself coming directly from God, as Augustine mentions in his On the Free Choice of the Will. Augustine mentions that freedom "is genuine only if it belongs to happy people who adhere to the eternal law." 32 Thus personhood for Augustine necessarily requires the presence of freedom and not merely self-awareness. Free will, in this sense, can be seen as having two characteristics: (1) innate and (2) creative. Innate for the reason that free will is an internal part of the person, and that the exercise of subjectivity is largely based on the functioning of his free will. (2) It is creative in a sense that man creates himself out of his free will. Augustine argues:

Instead, it is because they willed to live rightly, which evil people are unwilling to do. For this reason, it is no wonder that unhappy people do not attain what they will, namely the happy life. They do not likewise will what goes along with it, namely living rightly, and without willing this no one is worthy of the happy life or attains it. 33

Here Augustine explains how the person, endowed with free will, is the only agent capable of shaping his own experience of life. The happy life is willed (i.e., rooted in free will), and that the only true source of this life is the direct volition of the person. It becomes creative because free will as possessed by the person is his own creation.

We have seen how the existentialist Søren Kierkegaard has defined the essence of being a subject as possessing inwardness or self-awareness, and the capacity for communication. Self-awareness in Kierkegaard includes not only an affirmation of one's subjectivity, but also the capacity to perform actions through choices. Communication involves the intersubjective element, concretely showing how subjectivity is not a solipsistic ideology, but a communal, yet inward one.

Augustine's view of the person contains several elements that express this fundamental concept of subjectivity. The subject or self, as both

\footnotetext{
32 Augustine, On the Trinity, 27.

${ }^{33}$ Augustine, On the Free Choice of the Will, 25. Italics added.
}

(C) 2016 John Paulo Juliano http://www.kritike.org/journal/issue 19/juliano december2016.pdf ISSN 1908-7330 
experiencing and self-aware, is seen in the Augustinian Person. The person in Augustine does not live a passive existence. He is attuned to the workings of his mind and is aware of the development of his intellect. Human Dignity expresses an awareness of oneself as imago Dei, and not merely a shady part of general existence. Augustinian free will highlights the self's ability to choose, and the innate capability to make a choice. The existential concept of subjectivity, as having self-awareness and the capacity for choice, can be concretely seen in the self-affirming person of Augustine, who possesses free will as a necessary faculty from the Divine. Existentialism can trace its understanding of the subject to the very essence of the Augustinian person as imago Dei and having free will.

\section{Original Sin and the Earthly City}

The previous part of this essay presented how the Augustinian person expresses the very meaning of subjectivity in today's existentialist understanding. The second concept, which is despair, can be found in two important points of Augustine's philosophy: original sin and the earthly city. From this moment, then, the flesh began to lust against the spirit. With this rebellion, we are born, just as we are doomed to die and, because of the first sin, to bear, in our members and vitiated nature, either the battle with or defeat by the flesh. ${ }^{34}$

The very source of our defeat as human creatures lies in the concept of original sin. Augustine, in his work De Civitate Dei, outlines the development of man as an individual possessing original sin to his membership in a society or civitas. This explains how human beings have a tendency to commit evil deeds. ${ }^{35}$ The presence of original sin also lessens the dignity of his person, and renders him incapable of controlling his very base desires. The nature of men, as defined by Augustine, does not merit a high degree of perfection due to the presence of original sin. Hence, the person loses 'mastery' over his body:

The fact is that the soul, which had taken perverse delight in its own liberty and disdained the service of God, was now deprived of its original mastery over the

\footnotetext{
${ }^{34}$ Augustine of Hippo, The City of God, trans. by Gerard Walsh, et al (New York: Image Books, 1958), 278-279. Augustine speaks of this first sin as something that causes us being "soiled by sin and doomed to death and justly condemned."

35 This has been called by other thinkers, most notably Thomas Aquinas, as concupiscence or a 'tendency to sinful nature.'

(c) 2016 John Paulo Juliano

http://www.kritike.org/journal/issue 19/juliano december2016.pdf

ISSN 1908-7330

$((c))$ BY-NC-ND
} 
body; because it had deliberately deserted the Lord who was over it ... ${ }^{36}$

One comes to the understanding that original sin, as something inherent in the nature of man, is an individual element. Augustine does not stop at the individual element. The rest of the De Civitate talks about man with original sin progressing towards the establishment of a society and social order. This brings the discussion to the concept of the earthly city which can also be found in the other parts of the De Civitate.

The city of man, for all the width of its expansion throughout the world and for all the depth of its differences in this place and that, is a single community. The simple truth is that the bond of a common nature makes all human beings one. ${ }^{37}$

Augustine recognizes two things in this passage: (1) the city of men is a unified community, meaning that the state of affairs within this particular group is in harmony because of the cooperation of each member. However, he also points us to a different truth. (2) Augustine mentions 'the bond of a common nature.' This implies the human condition of original sin, wherein the unity that is present in the city of men is not out of an emphatic nature. It comes from the commonality of each member, as being immersed in the state of original sin. The city of men or the earthly city is a community precisely of the earth. It concerns itself with mundane affairs that will not help man in his self-fulfillment. Augustine continues:

Nevertheless, each individual in this community is driven by his passions to pursue his private purposes. Unfortunately, the objects of these purposes are such that no one person (let alone, the world community) can ever be wholly satisfied. ${ }^{38}$

The very aim of the earthly city and its constituents is precisely earthly happiness. This comes to a point where Augustine says that "Man indeed desires happiness even when he does so live as to make happiness impossible." 39 Man is unaware of the futility of his actions. Individually, man is tainted by original sin. He then lives in a society of individuals who share

\footnotetext{
${ }^{36}$ Augustine, The City of God, 278.

37 Ibid., 392.

${ }^{38}$ Augustine, The City of God, 392.

${ }^{39}$ Ibid., 300.
} 
the same nature, and are fated to aspire for happiness that cannot be achieved from a sinful nature and an earthly city.

Despair, as discussed previously, is the inability to be self-aware and to adhere to one's own subjectivity. His identity is blurred, and the ability for self-reflection becomes clouded. Augustine's philosophy expresses these points in original sin and the earthly city. The Augustinian person is exposed to despair and suffering, upon learning (1) the human condition as subject to Original Sin, and (2) the imperfection of his society as nothing more than an earthly city incapable of attaining true happiness and justice. With these presented, the Person is plunged into despair and imperfection. His true nature is hidden from him, and the perfection for which he aspires for becomes an impossibility. Held by original sin and forced to dwell within the city of men, man is subject to the effects of original sin and the futility of his society in aspiring for happiness. In light of this truth, man plunges into despair, and becomes acutely aware of his wretchedness and deceit. Augustine's person is no different from the single individual whose existence is rattled by an awareness of the 'ordinary-ness' of his existence. The subject's true nature is exposed to him, and leads him to despair.

\section{Inward Journey of the Self to God}

"Hear me, O God! Woe to the sins of men!" When a man cries thus, thou showest him mercy, for thou didst create the man but not the $\sin$ in him." 40 The person in Augustine is not entirely separated from the Divine due to his condition. It is true that original sin and the influence of the earthly city are antipathetic to the true nature of man. Augustine recognizes this truth, but also speaks of a 'redemption' for man. This initiates the journey of man to this redemption; a journey of the subject or the self back to his source, who is the Divine.

Let us see where the boundary line, so to speak, between the outer and the inner man is to be placed. For it is correctly said that whatever we have in our soul in common with the beasts pertains to the outer man, since by "outer man" we mean not the body alone, but also its own peculiar kind of life, from which the structure of the body and all the senses derive their vigor and by which they are equipped to perceive external things. ${ }^{41}$

\footnotetext{
${ }^{40}$ Augustine, Confessions, 6 .

${ }^{41}$ Augustine, On the Trinity, 82.
} 
In the De Trinitate, Augustine mentions the difference between the 'outer man' and the 'inner man.' This distinction is not the same with modern 'subjective-objective' pair. The outer man also involves human faculties that join us to the world like imagination and memory. ${ }^{42}$

No one doubts that, as the inner man is endowed with understanding, so the outer man is endowed with bodily sense ... For the teaching of the Apostle is clear, where he says that the inner man is being renewed in the knowledge of God according to the image of Him who created him [cf. Colossians 3:10]; and when he also says in another place: "Even though our outer man is decaying, yet our inner man is being renewed day by day" [2 Corinthians 4:16].43

This clearly indicates the precedence of the 'inner man' over the 'outer man' in the context of Augustine's philosophy. The emphasis on the inward journey characterizes Augustinian philosophy itself. It is a going back to God, who is the source of all things. In his Confessions, Augustine writes:

But thou, O Lord, whose life is forever and in whom nothing dies - since before the world was, indeed, before all that can be called "before," thou wast ... and with thee abide all the stable causes of all unstable things, the unchanging sources of all changeable things, and the eternal reasons of all non-rational and temporal things. ${ }^{44}$

Augustine acknowledges that God is indubitably the source of all things. Hence the argument follows that what comes from God as his creation must necessarily come back to him. From this line of thinking we may call this as the telos of man. ${ }^{45}$ The person, who is culled from the imago Dei, has as its natural destination his Creator-the very culmination of the inner man's journey.

${ }^{42}$ Istvan Siklosi, "The Self-Awareness and the Formal Concept of Person by Augustine and Boethius," in International Relations Quarterly, 4:1 (2013), 8. Hence epistemological functions are also classified under the 'outer man' even if they are natural qualities.

${ }^{43}$ Augustine, On the Trinity, 60-61. Italics added.

${ }^{44}$ Augustine, Confessions, 5.

${ }^{45}$ I have qualified the term 'telos' to mean (1) destination or the end of the person and (2) how Augustine describes the return to the 'stability' of God in Book IV of the Confessions as a culmination of life.

(c) 2016 John Paulo Juliano

http://www.kritike.org/journal/issue 19/juliano december2016.pdf

ISSN 1908-7330 
Let us now, O Lord, return that we be not overturned, because with thee our good lives without blemish-for our good is thee thyself. And we need not fear that we shall find no place to return to because we fell away from it. For, in our absence, our home-which is thy eternity - does not fall away. ${ }^{46}$

Passion as an existential concept was described in a previous discussion as an empowerment to live, and to live authentically and genuinely. To have passion for something or someone is to be actively engaged in it, and to be fully interested in this or that particular person or object. However, Sartre gives us another interpretation of passion in Existentialism is a Humanism, stating that:

Existentialists do not believe in the power of passion. They will never regard a great passion as a devastating torrent that inevitably compels man to commit certain acts and which, therefore, is an excuse. They think that man is responsible for his own passion. ${ }^{47}$

Yet passion is not simply restricted to emotions. Passions have both a teleological and rational aspect, as evident in the philosophy of Augustine. His concept of the inward journey and God as the ultimate telos of man, expresses the fundamental notion of passion as teleological. While the earlier mentioned rationality of man keeps passion within an objective realm that does not restrict itself to the purely emotional. Passion, then, still has an objective aspect.

The Augustinian Person, after having searched for his true meaning externally, begins his journey toward himself. His telos is none other than God, who is the Supreme fount of Wisdom. This telos drives the person, and creates in him an intense passion and desire that creates a will-to-live in itself. The source of this will-to-live does not come from an awareness of death and decay, nor of the seemingly pointless effort to know the meaning of our lives. It comes from the awareness that the Divine is the destination, and the journey toward the Divine is a crucial one. Passion blooms from this innerawareness of the Divine, and the journey itself is fueled by this truth.

\footnotetext{
${ }^{46}$ Augustine, Confessions, 64.

47 Jean-Paul Sartre, Existentialism is a Humanism, trans. by Carol Macomber (London: Yale University Press, 2007), 29.

(c) 2016 John Paulo Juliano

http://www.kritike.org/journal/issue 19/juliano december2016.pdf

ISSN 1908-7330

(c) BY-NC-ND
} 


\section{Conclusion}

Existentialism is, in essence, an approach to life and the different nuances that it presents to us. This approach is characterized by a centering on the subject, who experiences reality as an existing subject. The subject and his existence are the cornerstones of an existentialist theory. This truth, however, does not limit itself to the thinkers of modern and post-modern thought as we have seen in the course of this essay. Existentialism owes its foundations to thinkers of ancient and medieval thought most notably Augustine of Hippo, whose thought and relation to existentialism is the main argument of this paper.

The Augustinian Person, having human dignity and free will, is able to recognize his own subjectivity. However, his awareness of his person also reminds him of his temporality and imperfection, made known by the human condition of original sin and the social condition of living in an earthly city. Yet in spite of this, the person is led toward himself in a journey for the telos, who is God Himself, to whom the self aspires for in the journey of existence and ultimately, life. Gordon Lewis gives us a gist of this truth when he said that "Augustine has an existentialist standpoint of human fallenness, an emphasis on the existing individual, and an existential attitude of involvement." 48 His philosophy is marked by this precise focus on the existence of the individual, and how this existence is conditioned by the effects of original sin, as well as the journey of the individual, toward God who is his ultimate telos.

The Graduate School, University of Santo Tomas, Philippines

\section{References}

Aho, Kevin, Existentialism: An Introduction (Cambridge: Polity Press, 2014).

Alex, Ben, Soren Kierkegaard: An Authentic Life (Copenhagen: Scandinavia Publishing House, 1997).

Augustine of Hippo, Augustine of Hippo: Selected Writings, ed. by Mary T. Clark (New York: Paulist Press, 1984).

On the Free Choice of the Will, On Grace and Free Choice, and Other

Writings, trans. and ed. by Peter King (Cambridge: Cambridge University Press, 2010).

On the Trinity, trans. by Stephen McKenna and ed. by Gareth Matthews (Cambridge: Cambridge University Press, 2002).

48 Gordon Lewis, "Augustine and Existentialism," in Bulletin of the Evangelical Theological Society, 8:1 (1965), 22.

(c) 2016 John Paulo Juliano

http://www.kritike.org/journal/issue 19/juliano december2016.pdf

ISSN 1908-7330

(cc) BY-NC-ND 
The City of God, trans. by Gerard Walsh, et al. (New York: Doubleday Publishers, 1958).

The Confessions, trans. and ed. by Albert Cook Outler (New York: Dover Publications, Inc., 2014).

Collins, James, Crossroads in Philosophy (Chicago: Henry Regnery Company, 1969).

Descartes, René, Discourse on Method trans. by Laurence Lafleur (New York: The Liberal Arts Press, 1960).

Meditations on First Philosophy, ed. and trans. by John Cottingham (Cambridge: Cambridge University Press, 1996).

Kainz, Howard, G.W.F. Hegel: The Philosophical System (New York: Twayne Publishers, 1996).

Kierkegaard, Søren, Concluding Unscientific Postscript to Philosophical Fragments, trans. by Howard and Edna Hong (New Jersey: Princeton University Press, 2004).

Papers and Journals: A Selection, trans. by Alastair Hannay (London: Penguin Books, 1996).

Sickness Unto Death, trans. by Alastair Hannay (London: Penguin Books, 2008).

Lewis, Gordon, "Augustine and Existentialism" in Bulletin of the Evangelical Theological Society, 8:1 (1965).

Merleau-Ponty, Maurice, Phenomenology of Perception, trans. by Colin Smith. (New York: Routledge, 2003).

Sartre, Jean-Paul, Being and Nothingness, trans. by Hazel Barnes (New York: Pocket Books, 1971).

Existentialism is a Humanism, trans. by Carol Macomber (London: Yale University Press, 2007).

Siklosi, Istvan, "The Self-Awareness and the Formal Concept of Person by Augustine and Boethius," in International Relations Quarterly, 4:1 (2013).

Sousa, Domingos, "Kierkegaard's Anthropology of the Self: Ethico-Religious and Social Dimensions of Selfhood," in The Heythrop Journal, 53:1 (2012).

Tanzer, Mark, On Existentialism (California: Thomson Wadsworth, 2008). 